\title{
Leverage Measurement and Multinational Comparison of Listed Commercial Banks in China
}

\author{
Yuxin Lin, Mingdong Cheng, Kengfung Wong, and Ho Jacko Cheung
}

\begin{abstract}
Based on the provisions of Basel III and the Method for Leverage Management of Commercial Banks promulgated by China Banking Regulatory Commission, this study measured various risk indicators such as leverage and non-performing loan (NPL) ratio of 15 listed commercial banks in China and compared the same type of data from several foreign commercial banks after the financial crisis. According to the NPL ratio data of the banks, the NPL ratios of major commercial banks in China were on an upward trend from 2011 to 2015. The ratio of major foreign commercial banks rose significantly during the financial crisis but declined after that. By comparing the trend of non-performing loans at home and abroad, we find that the trend of non-performing loans in China is similar to the eve of the financial crisis in the United States.According to bank leverage data, the level of leverage of most domestic banks in China at this stage is still under prudential regulation, though over-leverage exists in several banks. However, due to the widespread regulatory arbitrage, some of the businesses are not reflected in the bank's external and internal assets according to the actual risks. As a result, the official data may underestimate the real leverage of the banking industry.An important factor is the rapid development of shadow banking. The macro-prudential supervision policy is in its initial stage of implementation and is expected to control the risks of commercial banks in China in the future.
\end{abstract}

Index Terms-Leverage ratio, Basel III, macro prudential supervision, non-performing loan ratio.

\section{INTRODUCTION}

After the financial crisis in 2008, due to the global economic slowdown, the return on investment in the real economy fell. Central banks around the world unanimously adopted loose monetary policies to support enterprises in restoring their balance sheets and economic recovery. At the same time, with the increase of government financing demand and the low interest rates, financial institutions enlarged investment returns by adding leverage.

The phenomenon of high leverage rises the attention from financial regulatory authorities, and the government began to work to combat all kinds of improper arbitrage, reduce the speculative funds in the financial sector, and guide the flow of funds into the real economy. At home, at the end of 2015, China proposed supply-side reform and made efforts to solve the three-phase overlay problem.

Manuscript received March 9, 2018; revised May 12, 2018.

Yuxin Lin, Mingdong Cheng, and Ho Jacko Cheung are with International School, Jinan University, China (e-mail: lucaslin1997@foxmail.com, 13927790257@163.com, jackocheung@qq.com).

Kengfung Wong is with HKUST Business School, The Hongkong University of Science and Technology (e-mail: kenwongkengfung@163.com.).
With the deepening of supply-side structural reforms, the elimination of production capacity, inventory reduction, cost reduction and making up shortages have been achieved, and the real economy has also enjoyed a positive grown. But deleveraging is somewhat complicated. On the one hand, the leverage of the real sector is still steadily rising, especially in the governmental departments and the residential sector. On the other hand, under the precautionary policy premise, the issue of leverage in the financial industry has begun to attract the attention of all parties and is becoming the focus of macroeconomic control. In particular, the deleveraging of financial institutions has become the focus this year.

Looking back at the 2008 financial crisis, one of the important reasons for its outbreak is that many countries' banks have implemented excessive internal and external leverage. As a result, the entire financial system is highly leveraged. This is essentially due to the financial innovation of financial products, especially financial derivatives. Based on the original asset-backed securities, the continuous development of financial derivatives has rapidly brought the financial system to a high level of leverage. The era of excessive internal and external leverage result in the deterioration of the level and quantity of capital base [1].

The crisis not only reflected the fragility of the existing banking system, but also exposed the lack of risk control. As a result, the BIS promulgated the Basel III aimed at strengthening the regulation of commercial banks in 2010 , which not only delayed the capital adequacy ratio of the past as a regulatory indicator, but also introduced the leverage ratio, which reflects the operation risk of commercial banks of the new indicators and clearly gives the lowest range, requiring the bank's operational safety to be upgraded.

China has made a positive response to this trend. The Guidelines on the implementation of New Regulatory Standards in China's Banking Industry in April 2011, the Commercial Banks Leverage Measures for the Administration of Liquidity in June 2011, Trial Measures for Liquidity Risk Management of Commercial Banks (Draft for Comment) in October 2011 and Measures for the Administration of Capital of Commercial Banks (for Trial Implementation) in June 2012 were promulgated respectively, determining capital adequacy ratio, leverage ratio, liquidity and loans loss preparation as the core regulatory standards to accurately reflect the commercial banks' individual and systemic risks based on the requirements of Basel III [2].

Deleveraging of the financial sector accompanied by supply-side reform is in full swing. However, since it is a short time after China takes leverage as a regulatory indicator, there are only a limited number of studies and 
understandings in the society. Therefore, a comprehensive and clear understanding of the status quo of commercial banks in China is precisely the purpose of the research. We decided to measure the current situation of the leverage of 16 listed commercial banks in our country and analyzed the leverage of commercial banks in China based on the leverage data of the major banks in the countries that suffered major damage in the financial crisis in 2008 from both time and space to form a comprehensive survey of the current situation and uncover the business conditions of China's commercial banks [3].

\section{METHODOLOGY AND DATA}

\section{A. Measurement Methodology}

The leverage ratio is a non-sensitive, comparatively simple monitoring and control measure, defined as

Leverage ratio=total assets/tier 1 capital

Tier 1 capital=common shares+retained earnings+additional elements

According to the calculation method above of the leverage ratio, we select 15 domestic listed commercial banks and foreign commercial bank representatives-American Bank and Sumitomo Mitsui Banking Corporation. Collecting data from Bankscope and Bloomberg, the data of domestic banks last from year 2009-2016 and the data of foreign banks last from year 2006-2015, regarded as the core data of this paper as well as making direct comparison among the leverage ratio of domestic and foreign banks [4].

\section{B. The Rising non-Performing Loan Ratio}

Different from the real economy, the financial industry itself is a highly leveraged industry. It is because of this highly leveraged ratio that social funds are collected and led to the most efficient areas so as to promote the development of the real economy. Of course, high leverage will inevitably mean high risk. When the leverage exceeds a reasonable level, the vulnerabilities of financial institutions and even the financial system will also rise. The probability of a financial crisis will increase greatly. From the perspective of sustainable development, it is necessary for the financial industry to control the leverage at a reasonable level so as to balance risk and efficiency. According to the data disclosed by China Banking Regulatory Commission, the non-performing loan ratios of medium and large commercial banks, joint-stock commercial banks, urban commercial banks and rural commercial banks all showed an upward trend from 2013 to 2015, of which the ratio of non-performing loans of rural commercial banks was the highest, reaching $2.5 \%$ in 2015 , followed by a large commercial bank. With the gradual increase in credit risk, high leverage will undoubtedly increase the banking business risk [5].

\section{Leverage Contrast between Domestic and Foreign Commercial Banks}

According to definition of leverage ratio, the statistical size is 25 times of the highest level of capital leverage in Leverage Measures of Commercial Bank based on the China
Banking Regulatory Commission, and this paper will take the total assets divided by the equity capital to measure the bank leverage. By collecting data from authentic databases such as Bankscope, Bloomberg, wind, etc. of global banks and financial institutions, we calculate the data of leverage ratio of domestic listed commercial banks from 2011 to 2015 as shown below, as well as data of leverage changes of foreign commercial banks before and after the financial crisis. The two are compared cross-nationally.

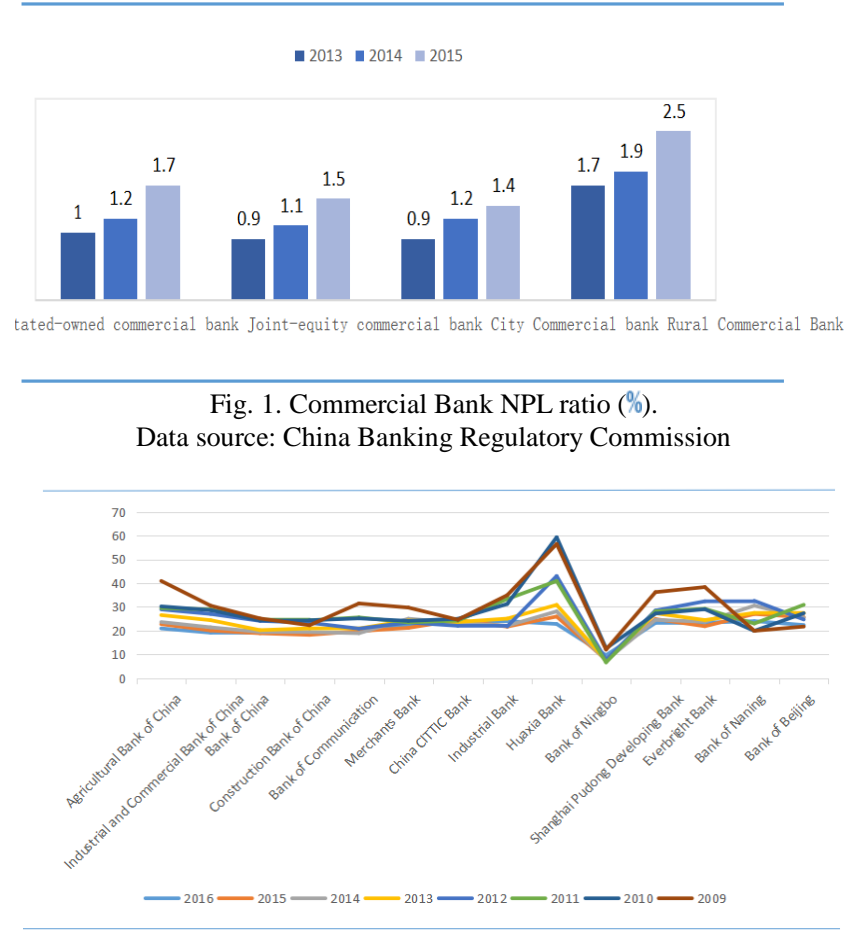

Fig. 2. Leverage ratio of major domestic commercial banks. Data source: Bankscope, Bloomberg, Wind, Author's calculation

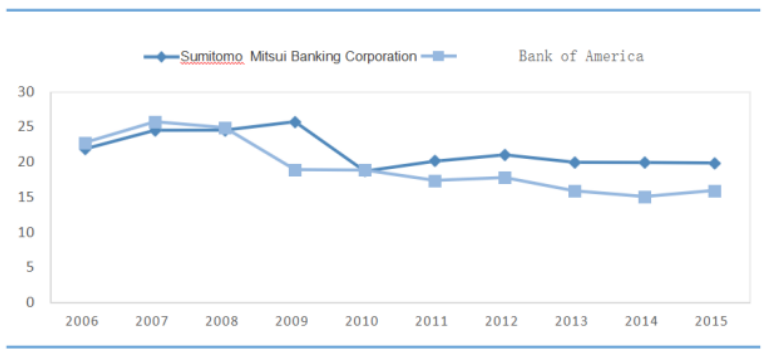

Fig. 3. Foreign commercial banks leverage.

Data source: Bankscope, Bloomberg, Wind, Author's calculation

Combined with the above data, the current banking industry is still under tight prudential regulation, and there is no excessive leverage usage. However, it should be pointed out that due to the widespread regulatory arbitrage, part of the business is not reflected in the bank's real-time and external assets according to the actual risks, leading to the fact that the official data may underestimate the real leverage of the banking industry; on the other hand, the fact that the overall banking leverage is not high level does not mean that all agencies are cautious. In contrast, a few small and medium-sized banks are more radical, and over-leverage exists, such as Huaxia Bank, Bank of Nanjing and Bank of Beijing. These banks are precisely the ones that need financial deleveraging. From the five-year trend between 2011 and 2015, the leverages of domestic commercial banks 
were at a relatively high level in 2011 . With the introduction of CBRC's regulatory policies, the leverage ratio had been declining gradually from 2012 to 2015. Foreign large commercial banks showed a marked upward trend in leverage before the financial crisis, and the leverage ratio gradually declined and remained stable after the financial crisis. The leverage of some domestic commercial banks is similar to those foreign ones which suffer from the financial crisis. [6]

\section{The Leverage and Credit Risk Status of Commercial Banks in China}

\section{Overall Analysis of NPL in China's Commercial Banks}

According to the data released by China Banking Regulatory Commission, the total non-performing loans of domestic commercial banks in the first quarter of 2015 was RMB 992.5 billion, an increase of RMB 139.9 billion from the same period of 2014, and the new non-performing loan ratio reached 982.5 billion yuan, up from the same period in 2014 3,364 billion yuan. And the latest non-performing loan rate reached $1.39 \%$, up 0.0875 percentage points over the same period in 2014, so the upward trend has shown signs of acceleration.NPL surges and banking risk management is challenged.

Non-performing loan ratios of major commercial banks also showed a clear upward trend, showing signs of acceleration in the first quarter of 2015. As of the end of March 2015, among the mainland 16 listed banks that have announced their results, ICBC, Agricultural Bank of China and China Construction Bank have the highest total amount of non-performing loans, totaling RMB 412.8 billion, accounting for $58 \%$ of the total non-performing loans. What is more serious is that the amount and ratio of overdue non-performing loans increased significantly. Overdue non-performing loans of 16 listed banks totaled 175.5 billion yuan by the end of 2016, exceeding the non-performing loan ratio of $0.36 \%$.

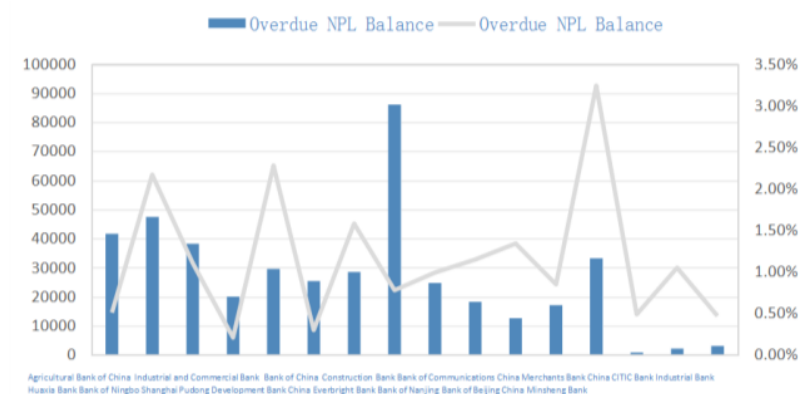

Fig. 4. Overdue NPL Balance and Ratio of 16 Listed Banks in 2016 (\%) Data source: China Banking Regulatory Commission

According to the latest quarterly data released by China Banking Regulatory Commission in the second quarter of 2017 , the ratio of non-performing loans of rural commercial banks accounts for a large proportion, while that of large commercial banks accounts for the largest share of total non-performing loans.

\section{Credit risk exposure and non-performing loan ratio increase}

As shown in the figure below, the non-performing loan ratio of various commercial banks further increased.
Although the trend of significant credit risk explosion has been eased between 2010 and 2013, the non-performing loan ratio of various commercial banks rebounded from late 2013 , and credit risk had re-exposed, showing a growing trend.

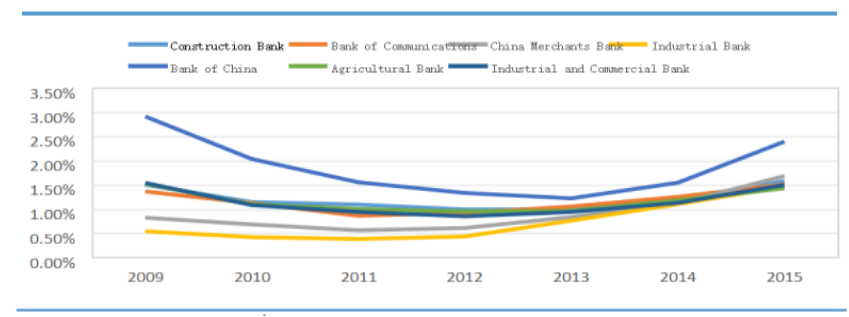

Figure 5 Non-performing loan ratio of some domestic commercial banks $(\%)$

Data source: wind, author's calculation.

As can be seen from the figure above, the commercial banks listed in the figure show a trend of rising non-performing loans after falling from 2009 to 2015 . During the financial crisis, the non-performing loan ratio was at the highest level in 2009 and then gradually declined. However, There was a rebound trend between 2012 and 2013, and the non-performing loan ratio showed a clear upward trend in 2015.

\section{DISCUSSION AND CONCLUSION}

\section{A. Rapid Expansion of Shadow Banks}

As mentioned above, due to the extensive existence of regulatory arbitrage, some of the businesses are not reflected in the bank's external and internal assets according to actual risks. As a result, the official data may underestimate the real leverage of the banking industry and make the asset and liability structure change continuously. The connotation of risk has changed. An important factor is the rapid development of shadow banks. China's shadow banking is caused by the fact that commercial banks to avoid regulation take the initiative to turn their resource out of the traditional deposit and to some extent share some of the commercial bank credit.

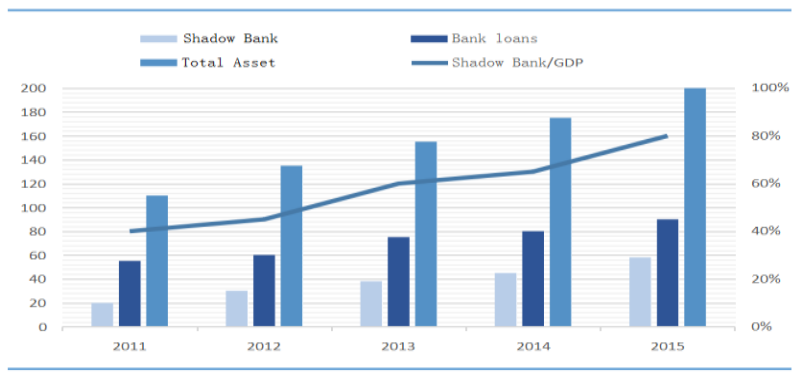

Fig. 6. China shadow banking scale (trillion yuan). Source: Moody

According to the international rating agency Moody's report on China's banking industry in 2016, shadow banking has taken an increasing share of bank loans and assets over the past few years. At of the end of 2015, the share in bank loans and assets have reached $80 \%$ and $60 \%$ respectively. The large shadow banking system means that banks may face difficulties in replacing shadow banking credit when the credit crunch is tight, and borrowers relying on such 
financing run the risk of a credit crunch. In addition, due to the high correlation between the conventional banking system and the shadow banking system, the large size of the shadow banking system will also amplify its spillover risk on the financial system. Therefore, the regulatory indicators set by the CBRC may not objectively reflect the current most real risk conditions of commercial banks in China [7].

\section{B. Future of Deleveraging}

Due to the rapid growth of off-balance-sheet wealth management services that have not been included in the macro prudential assessment (MPA) in the past few years, the business of some banks poses tremendous risks. First, the investment in the underlying assets of off-balance-sheet wealth management mainly includes assets such as credit and bonds. There is not much difference from general credit in the table. It also plays a role of credit expansion. If the growth is too fast, it will accumulate macro-risk, which is detrimental to deleveraging. The second is that while off-balance-sheet wealth management is named as off-balance sheet, the source of funds is to some extent rigidly paid. Banks often have to internalize the risks in the event of risks and do not really achieve risk segregation. Therefore, in order to measure risks more comprehensively and accurately and guide financial institutions to operate more prudently, the People's Bank of China formally started to include off-balance sheet wealth management in the scope of general credit when assessed in the first quarter of 2017 [8].

Macro prudential supervision requires that the credit expansion of financial institutions meets the reasonable needs of economic growth and its own capital level. As a credit institution that is a lever derivative of the economic system, the operating characteristics of financial institutions make it over-expanded and the modern financial system is becoming more and more complex, which poses a greater challenge to the regulation and normalization of the development of the industry [9]. The risk accumulation is more and more hidden, and the social impact caused by the risk events is also broadened. The purpose of macro prudential supervision is to balance the assets expansion with the capital level by establishing an effective capital restraint mechanism and ensure that the financial institutions have enough capacity to absorb the risk losses [10]. Therefore, the broad-based credit indicators that include off-balance-sheet wealth management into the macro-prudential evaluation system are in line with the regulatory risk control and leverage reduction [11], [12].

\section{REFERENCES}

[1] T. Jokipii and B. Milne, "Bank capital buffer and risk adjustment decisions," Journal of Financial Stability, vol. 14, pp. 1-14, February 2010.

[2] M. Frenkel and M. Rudolf, "The implications of introducing an additional regulatory constraint on banks' business activities in the form of a leverage ratio," Otto Beisheim School of Management, 2010 .

[3] P. M. Hidebrand, "Is Basel II enough? The benefits of a leverage ratio," London School of Economics, 2008.

[4] B. H. Cohen and M. Scatigna, "Banks and capital requirements: channels of adjustment," Journal of Banking \& Finance, vol. 14, pp. 56-69, August 2016.

[5] J. Caruna, "Macroprudential policy: Opportunities and challenges," Bank for International Settlements, 2014.

[6] B. Aronold, C. Borio, L. Ellis, and F. Moshirian, "Systemic risk, macroprudential policy frameworks, monitoring financial systems and the evolution of capital adequacy," Journal of Financial Stability, vol. 36, pp. 3125-3132, 2012.

[7] S.Ingves, "Challenges for the design and conduct of macroprudential policy,” BIS Working Paper, no. 60, 2014.

[8] S. G. Hanson, A. K Kashyap and J. C. Stein, "A macroprudential approach to financial regulation," Journal of Economic Perspective, vol. 11 , pp. $3-28,2011$

[9] J. Dermine, "Basel III leverage ratio requirement and the probability of bank runs," Journal of Banking \& Finance, vol. 53, pp. 266-277, 2015.

[10] R. Aggarwal, and K. T. Jacques, "Assessing the impact of prompt corrective action on bank capital and risk," Economic Policy Review, vol.10, pp. 23-32. 1998.

[11] T. Jokipii and A. Milne, "Bank capital buffer and risk adjustment decisions," Journal of Financial Stability, vol. 3, pp. 165-178, 2017.

[12] M. Frenkel and M. Rudolf, "The implication of introducing an additional regulatory constraint on banks' business activities in the form of a leverage ratio," German Banking Association, March, 2010.

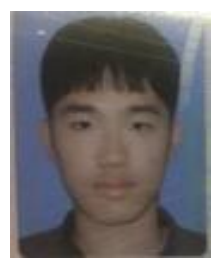

Yuxin Lin was born on August 11, 1997. He is a junior student at Jinan University, China. His main research field is commercial bank and its risk management.

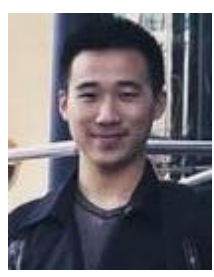

Mingdong Cheng was born on September 9, 1997. $\mathrm{He}$ is a junior student at Jinan University, China. His main research field is commercial bank and its risk management.

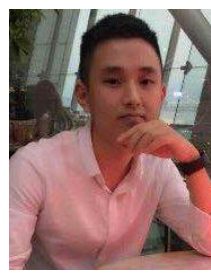

Kengfung Wong was born on September 4, 1995. He is a master student at The Hongkong University of Science and Technology. His main research field is commercial bank and its risk management.

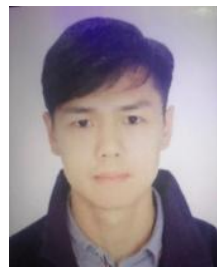

Ho Jacko Cheung was born on July 16, 1998. He is a sopromore student at Jinan University, China. His main research field is commercial bank and its risk management. 